\title{
PREPARATION OF Co, Ni, AND Zn-BASED CATALYST SUPPORTED ON MESOPOROUS CARBON FOR HYDROCRACKING OF PYROLYZED $\alpha$-CELLULOSE
}

\author{
Triyono, W. Trisunaryanti ${ }^{\bowtie}$, A. Syoufian, A. P. Wibawa, E. Suarsih, \\ and D.A. Fatmawati \\ Department of Chemistry, Faculty of Mathematics and Natural Sciences, \\ Universitas Gadjah Mada, Sekip Utara Bulaksumur Yogyakarta, 55281, Indonesia \\ ${ }^{\square}$ Corresponding Author: wegats@ugm.ac.id
}

\begin{abstract}
The Co, Ni, and $\mathrm{Zn}$ metal catalysts impregnated on mesoporous carbon from Merbau wood sawdust have been prepared and aimed to improve the hydrocracking activity of cellulose bio-oil into a functional liquid product. Carbonbased sawdust as catalyst support was carbonized at various temperatures which subsequently denoted as C500, C600, C700, and C800. The generated materials were characterized by GSA, FTIR, SEM, AAS, and acidity test. Meanwhile, the pyrolysis and hydrocracking results were investigated using GC-MS. The GSA analysis reveals that C800 had the largest specific surface area $\left(164.60 \mathrm{~m}^{2} \mathrm{~g}^{-1}\right)$ with an average pore diameter of $3.80 \mathrm{~nm}$ and pore volume of $0.15 \mathrm{~cm}^{3}$ $\mathrm{g}^{-1}$ which makes it preferable as catalyst support. Among all the catalysts, $\mathrm{Zn} / \mathrm{C} 800$ had the highest metal content of 0.88 wt.\% as well as the highest acidity of $9.68 \mathrm{mmol} \mathrm{g}^{-1}$. The three dominant compounds produced from hydrocracking of pyrolyzed $\alpha$-cellulose were $\mathrm{C}_{3} \mathrm{H}_{6} \mathrm{O}_{2}, \mathrm{C}_{2} \mathrm{H}_{4} \mathrm{O}_{2}$, and $\mathrm{C}_{5} \mathrm{H}_{4} \mathrm{O}_{2}$.

Keywords: Merbau Wood Sawdust, Mesoporous Carbon, Metal, Hydrocracking, Pyrolysis, $\alpha$-cellulose

RASĀYAN J. Chem., Vol. 14, No.3, 2021
\end{abstract}

\section{INTRODUCTION}

The development of renewable resources for energy and transportation fuels has increased due to declining fossil resources and environmental concerns. Several biological resources, especially cellulose from biomass, may become a promising raw material for the production of biofuel. ${ }^{1-4}$ The conversion of biomass into biofuel has got an important way for agricultural waste valorization. ${ }^{5}$ Effective and innovative researches on the production of biofuel from waste-based cellulose have been executed around the world. ${ }^{6,7}$ Currently, technologies for the conversion of cellulose into alkanes compounds have been widely reported. Thermolysis approaches such as pyrolysis are a powerful method for the chemical decomposition of cellulose into unstable bio-oil products. ${ }^{8-13}$ The stability of bio-oil can be improved through hydrotreatment which involves the use of hydrogen gas and a catalyst. During hydrotreatment, the hydrocracking and the polymerization reaction occur simultaneously at the elevated temperature. ${ }^{14,15}$

The conversion of the pyrolyzed cellulose into biofuel requires a good catalytic system so that energy efficiency can be achieved. ${ }^{16,17}$ General characteristics of excellent catalytic systems include high activity, good selectivity, and resistance to deactivation caused by poisoning or coke formation. ${ }^{16}$ Metal-based catalysts are extensively utilized directly as a catalyst without being impregnated on a support material for the cellulosic conversion into biofuel. However, this catalyst is not resistant to a high-temperature process. Types of this catalyst have low thermal stability and specific surface area. ${ }^{18}$ Therefore, the metal catalyst needs to be dispersed on support material to enhance the catalytic activity by increasing the active site's surface area. According to the previous report, ${ }^{19}$ the presence of metal will dehydrogenate the reactant to form carbonium ions which subsequently experience rearrangement or may make $\beta$-scission into shorter chains.

Various catalyst supports have been widely applied, but the use of inorganic compounds such as synthetic zeolites, silicates, and aluminates will complicate the recovery process of the metal thus causing 
RASĀYAN J. Chem.

Vol. 14 | No. 3 |1965-1971| July - September | 2021

environmental pollution. ${ }^{20}$ The utilization of carbon, specifically meso-sized, as catalyst support has many advantages such as acid and base resistance, high-temperature resistance, inert, large surface area, economically inexpensive, easy to obtain from carbon-contained material, and can be recovered. ${ }^{21}$ Pore size and specific surface area of the activated carbon have been evaluated to influence the reaction capacity and rate strongly. ${ }^{22}$

Merbau wood, which is one of Indonesia's endemic wood, is extremely demanded worldwide due to it can produce abundant sawdust. ${ }^{23}$ The maximum application of biomass waste can be accomplished by using wood sawdust as a carbon source for the synthesis of the catalyst support. The mesoporous carbon can be prepared by utilizing surfactant as a template. ${ }^{24}$ Nevertheless, this use has its environmental impact after being utilized.

Corresponding to these considerations, the mesoporous carbon was synthesized by using Merbau wood sawdust as a raw material without a template. The obtained mesoporous carbon was impregnated with transition metals like $\mathrm{Co}, \mathrm{Ni}$, and $\mathrm{Zn}$ through the simple wet impregnation method. The catalytic performance of resulted catalysts was investigated in the hydrocracking of pyrolyzed $\alpha$-cellulose.

\section{Material and Methods}

\section{EXPERIMENTAL}

The carbon support material was prepared from Merbau wood sawdust originated from Manokwari, North Papua, Indonesia. The salt precursors of $\mathrm{NiCl}_{2} \cdot 6 \mathrm{H}_{2} \mathrm{O}, \mathrm{ZnCl}_{2} \cdot 6 \mathrm{H}_{2} \mathrm{O}$, and $\mathrm{CoCl}_{2} \cdot 6 \mathrm{H}_{2} \mathrm{O}$ were supplied by Merck. The $\mathrm{N}_{2}$ and $\mathrm{O}_{2}$ gasses were purchased from Samator Ltd.

\section{Synthesis and characterization of carbon support material}

The Merbau wood sawdust was dried at $105{ }^{\circ} \mathrm{C}$ for 4 hours. Afterward, it was placed in a tubular furnace and carbonized under $\mathrm{N}_{2}$ gas $(20 \mathrm{~mL} / \mathrm{min})$ for 120 minutes at various temperatures of $500{ }^{\circ} \mathrm{C}(\mathrm{C} 500), 600$ ${ }^{\circ} \mathrm{C}(\mathrm{C} 600), 700{ }^{\circ} \mathrm{C}(\mathrm{C} 700)$, and $800{ }^{\circ} \mathrm{C}(\mathrm{C} 800)$. The dried carbon obtained was oxidized by streaming 20 $\mathrm{mL} \mathrm{min}{ }^{-1} \mathrm{O}_{2}$ gas at $350{ }^{\circ} \mathrm{C}$ for 180 minutes. The oxidized carbon was mashed up until its particle size of 80 mesh. The resulted carbon support was analyzed by GSA to determine its physical properties like specific surface area and pore size, and FTIR to investigate its characteristic functional groups. The mesoporous carbon with the highest specific surface area was further analyzed by SEM and utilized for the metal impregnation process.

\section{Impregnation of $\mathrm{Co}, \mathrm{Ni}$, and $\mathrm{Zn}$}

The $\mathrm{Co}^{2+}, \mathrm{Ni}^{2+}$, and $\mathrm{Zn}^{2+}$ with the same metal loading amount of $2 \mathrm{wt} . \%$ were impregnated into mesoporous carbon by the wet impregnation method. Each salt precursor was dissolved in water and dispersed into the mesoporous carbon. The mixtures were stirred at $80^{\circ} \mathrm{C}$ for 120 minutes. The obtained solids were filtered, washed using bi-distilled water, then dried at $105^{\circ} \mathrm{C}$ for 4 hours. The dried solids were calcined in the furnace under $\mathrm{N}_{2}$ gas $\left(20 \mathrm{~mL} \mathrm{~min}^{-1}\right)$ at $400{ }^{\circ} \mathrm{C}$ for 3 hours and reduced by $20 \mathrm{~mL} \mathrm{~min}^{-1} \mathrm{H}_{2}$ gas for 3 hours. Each impregnated carbon was further characterized by AAS to calculate the metal amount in the mesoporous carbon. The resulted impregnated carbon was applied in the hydrocracking process to investigate its catalytic performance.

\section{Catalyst Test}

The catalytic activity of the prepared catalysts was tested for the conversion of $\alpha$-cellulose into biofuel. It was carried out by the hydrocracking process in the cracking reactor. Firstly, $\alpha$-cellulose was liquified through the pyrolysis process by streaming $\mathrm{N}_{2}$ gas with a flow rate of $20 \mathrm{~mL} \mathrm{~min}^{-1}$ at $600{ }^{\circ} \mathrm{C}$ using the same reactor. The pyrolyzed $\alpha$-cellulose was applied as a feed of the hydrocracking process. Each catalyst and feed with the weight ratio of 1:30 was placed in the reactor and streamed by $\mathrm{H}_{2}$ gas with a $20 \mathrm{~mL} \mathrm{~min}^{-1}$ flow rate at $400{ }^{\circ} \mathrm{C}$ for 2 hours. The obtained liquid product was analyzed by GC-MS.

\section{Detection Method}

The textural properties of the mesoporous carbons were examined by using a Gas Sorption Analyzer (GSA, Quanta-chrome Nova Win version 11.0). The typical functional groups of mesoporous carbons were 
RASĀYAN J. Chem.

Vol. 14 | No. 3 |1965-1971| July - September | 2021

characterized by Fourier Transform Infra-Red Spectrometer (FTIR, Shimadzu Prestige 21) at a wavenumber range of 4000-400 $\mathrm{cm}^{-1}$. The surface morphology of the mesoporous carbons was taken by Scanning Electron Microscope (SEM, JEOL JSM-6510). Atomic Absorption Spectrophotometer (AAS, Perkin Elmer 5110-PC) was utilized to estimate the metal content of catalysts. The total acid amount of the catalysts was tested by the gravimetric method using $\mathrm{NH}_{3}$ vapor adsorption. The liquid products of the hydrocracking result were analyzed using Gas Chromatography-Mass Spectrophotometer (GC-MS, Shimadzu QP2010S).

\section{Synthesis and Characterization of Mesoporous Carbon \\ RESULTS AND DISCUSSION}

The mesoporous carbon was synthesized from Merbau wood sawdust via carbonization under several temperatures. During carbonization, the sawdust was heated in a closed vessel by streaming the $\mathrm{N}_{2}$ gas. The absence of oxygen makes the wood substances decomposed into various compounds with a porous black carbon solid as the major product. The mass of carbon obtained after the process is inversely proportional to the temperature of carbonization. Figure-1 shows that the higher the carbonization temperature, the more amount of mass loss during carbonization. This is due to the pressure that arises resulting in the sawdust decomposed more.

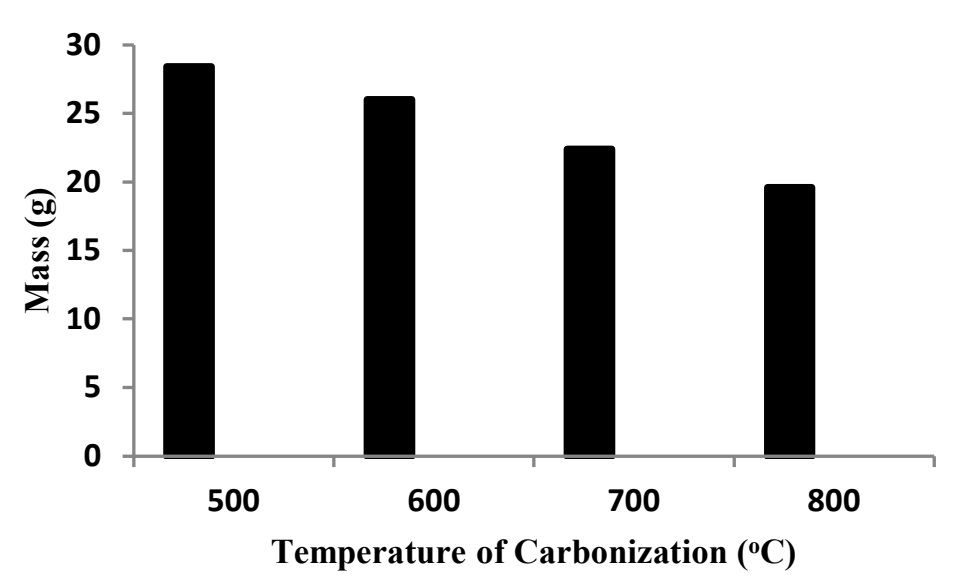

Fig.-1: The relations between the temperature of carbonization and the mass of carbon after carbonization

The textural properties of carbonized sawdust were analyzed using Gas Sorption Analyzer (GSA). The GSA data are shown in Table-1. According to the results below, the obtained solid carbons have an average pore diameter between 3.8 to $13.6 \mathrm{~nm}$ where this range is categorized as mesopores. The specific surface area of mesoporous carbons increases while the pore diameter decreases along with the increase in temperature of carbonization. The C800 has the highest specific surface area of $164.60 \mathrm{~m}^{2} \mathrm{~g}^{-1}$ and the smallest pore diameter of $3.8 \mathrm{~nm}$. This result is following the theory which states that a smaller pore diameter will generate a larger specific surface area. The specific surface area of mesoporous carbon will affect its activity as catalyst support because it will provide a larger deposition area of the metal catalyst.

Table-1: Textural Properties of Mesoporous Carbon

\begin{tabular}{c|c|c|c}
\hline Sample & $\mathrm{S}_{\mathrm{BET}^{\mathrm{a}}}{ }^{\left(\mathrm{m}^{2} / \mathrm{g}\right)}$ & $\mathrm{V}_{\text {tot }^{\mathrm{b}}}(\mathrm{cc} / \mathrm{g})$ & $\mathrm{D}_{\mathrm{p}}{ }^{\mathrm{c}}(\mathrm{nm})$ \\
\hline $\mathrm{C} 500$ & 37.13 & 0.13 & 13.6 \\
\hline $\mathrm{C} 600$ & 59.03 & 0.11 & 7.6 \\
\hline $\mathrm{C} 700$ & 97.01 & 0.13 & 5.2 \\
\hline $\mathrm{C} 800$ & 164.60 & 0.15 & 3.8 \\
\hline
\end{tabular}

${ }^{\mathrm{a}}$ specific surface area was calculated by the BET method

${ }^{b}$ total pore volume was determined from the adsorption of nitrogen gas at a relative pressure

${ }^{\mathrm{c}}$ average pore diameter was estimated by the $\mathrm{BJH}$ method 
RASĀYAN J. Chem.

Vol. 14 | No. 3 |1965-1971| July - September | 2021

The FTIR spectra in Fig.-2 show significant changes in peak intensity, especially in transitioning carbonization temperature between $600{ }^{\circ} \mathrm{C}$ and $700{ }^{\circ} \mathrm{C}$. This is indicated that at temperature $600{ }^{\circ} \mathrm{C}$ the sawdust had been partially decomposed whereas at $700{ }^{\circ} \mathrm{C}$ it had been fully decomposed. Based on the spectra, the peaks in the wavenumber range of $817-879 \mathrm{~cm}^{-1}$ denote an aromatic $\mathrm{C}-\mathrm{H}$ bending vibration of the lignin character as a biomass constituent component, the peaks at $1095-1172 \mathrm{~cm}^{-1}$ expresses the $\mathrm{C}-\mathrm{O}$ vibration of the ester group, peak at $1388 \mathrm{~cm}^{-1}$ appeared on $\mathrm{C} 800$ carbon represents the $\mathrm{C}=\mathrm{O}$ stretching vibration of the carboxylic acid group, peaks at $1543-1604 \mathrm{~cm}^{-1}$ shows the vibration of the aromatic $\mathrm{C}=\mathrm{C}$ resistance, peaks at $1681-1751 \mathrm{~cm}^{-1}$ exhibit the vibration of $\mathrm{C}=\mathrm{O}$ from the ketones, peaks at $2854-2985 \mathrm{~cm}^{-}$ ${ }^{1}$ reveal the vibration $\mathrm{C}-\mathrm{H}$ of alkane $-\mathrm{CH}_{2}$, and peaks at $3410-3448 \mathrm{~cm}^{-1}$ denote the vibration of O-H strain from hydroxyl group.

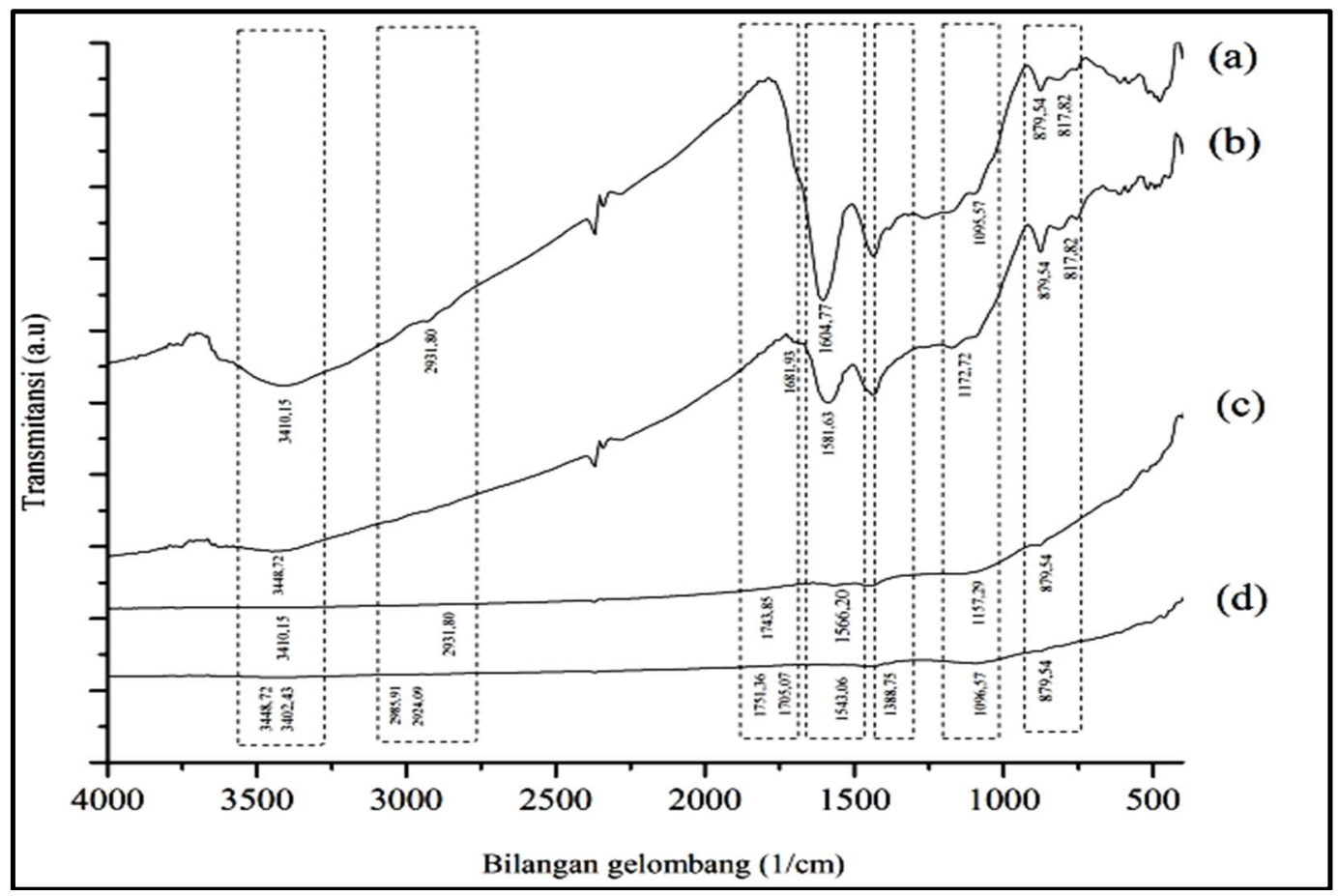

Fig.-2: The FTIR Spectra of (a) C500, (b) C600, (c) C700, and (d) C800

C800 has been chosen for further characterization using Scanning Electron Microscope (SEM) because it has the largest specific surface area and the most complete decomposition. Figure-3a and $3 \mathrm{~b}$ show the fragment's surface morphology of activated carbon using 1,000 and 10,000 times magnification. It can be seen that the carbon has layered and irregularly porous surfaces. It proves that the carbon structure resembles the irregularly overlapping hexagonal layers associated with Van der Waals forces. Also, the presence of pore structures on the carbon surface allows adsorbing other elements including transition metal ions so that the carbon can be applied as a catalyst carrier.
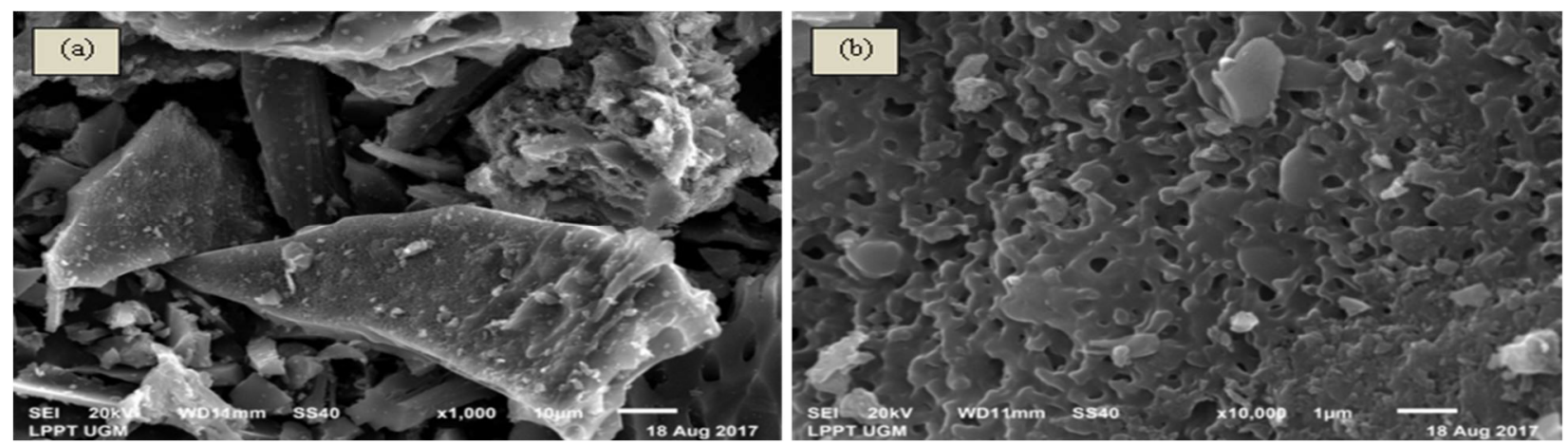

Fig.-3: The SEM image of C800 with (a) 1,000 times magnification and (b) 10,000 times of magnification 1968 
RASĀYAN J. Chem.

Vol. 14 | No. 3 |1965-1971| July - September | 2021

\section{Preparation and Characterization of $\mathrm{Ni} / \mathrm{C800}, \mathrm{Co} / \mathrm{C800}$, and $\mathrm{Zn} / \mathrm{C800}$ Catalysts}

The preparation of $\mathrm{Ni} / \mathrm{C} 800, \mathrm{Co} / \mathrm{C} 800$, and $\mathrm{Zn} / \mathrm{C} 800$ catalysts were carried out through a simple wet impregnation process by dispersing metal salt solution into the activated mesoporous carbon. According to the previous study, a mechanism that can occur during the impregnation stage is the chemical complexity. ${ }^{25}$ The concept of chemical complexity presupposes that there will be a specific interaction between certain metal ions and the functional groups on the carbon surface. Based on the Irving-Williams series, the general stability sequences of high spin complexes (octahedral metal) for water replacement by other ligands are $\mathrm{Mn}(\mathrm{II})<\mathrm{Fe}(\mathrm{II})<\mathrm{Co}(\mathrm{II})<\mathrm{Ni}(\mathrm{II})<\mathrm{Cu}(\mathrm{II})>\mathrm{Zn}(\mathrm{II}) .{ }^{26}$

Table-2: Chemical Properties of Catalysts

\begin{tabular}{c|c|c}
\hline Catalyst & Metal Content (wt.\%) & Acidity $\left(\mathrm{mmol} \mathrm{g}^{-1}\right)$ \\
\hline $\mathrm{C} 800$ & - & 5.24 \\
\hline $\mathrm{Co} / \mathrm{C} 800$ & 0.35 & 8.57 \\
\hline $\mathrm{Ni} / \mathrm{C} 800$ & 0.40 & 8.67 \\
\hline $\mathrm{Zn} / \mathrm{C} 800$ & 0.88 & 9.68 \\
\hline
\end{tabular}

Table-2 shows that the percentage of impregnated metal increases as the atomic number in the series of inner transition metals, where $\mathrm{Zn}$ metal is the highest percentage of $0.88 \mathrm{wt} \%$. The difference in the ability of carbon surface active site to bind different metals depends on the suitability of the metal ion radius as well as the symmetry of its valence electron orbitals with the active functional group. ${ }^{26}$ The impregnation of metals affects the acidity value of C800. Moreover, the acidity value of the catalyst increases along with the metal content due to the Lewis acid sites contained in it as presented in the table above. Based on the analysis results, $\mathrm{Zn} / \mathrm{C} 800$ has the highest metal content and acidity value.

\section{Catalytic Activity and Selectivity in Hydrocracking of Pyrolyzed $\alpha$-cellulose}

The examination of the catalytic activity and selectivity was performed through the hydrocracking process of pyrolyzed $\alpha$-cellulose bio-oil. The hydrocracking treatment that is executed after pyrolysis leads the biofuel produced more stable under the presence of hydrogen gas. This gas can bind to free radicals when heated to high temperatures. The formed free radicals will react with the feed and convert it into new compounds with shorter chains.

In a hydrocracking reaction, hydrogen gas will dissociate on the metal surface on the carrier, then the dispersed hydrogen turns into protons and hydrides. The proton will be the cracking reaction promoter through a protonation reaction forming a carbon site with $\beta$-acid. $\beta$-acid will initiate $\beta$-scission in the hydrocracking reaction. Whereas, the hydride will stabilize the formed carbonium ions to prevent excessive cracking and initiate the isomerization reaction of the alkanes. The product distribution of the hydrocracking process is shown in Table-3.

\begin{tabular}{|c|c|c|c|c|}
\hline \multirow[t]{2}{*}{ Catalyst } & \multicolumn{3}{|c|}{ Product Distribution (wt.\%) } & \multirow[t]{2}{*}{ Residue (wt.\%) } \\
\hline & Liquid & Gas & Coke & \\
\hline Thermal & 29.96 & 55.48 & - & 14.56 \\
\hline $\mathrm{Co} / \mathrm{C} 800$ & 42.00 & 45.33 & 2.67 & 10.00 \\
\hline $\mathrm{Ni} / \mathrm{C} 800$ & 76.67 & 18.38 & 1.64 & 3.31 \\
\hline $\mathrm{Zn} / \mathrm{C} 800$ & 75.33 & 13.13 & 2.91 & 8.63 \\
\hline
\end{tabular}

The data shows that the process using a catalyst generates more liquid products than without a catalyst (thermal). This is due to the formation of a carbocation as the intermediate compound of the reactant before turned into a product. The catalyst provides empty orbitals as the site of the carbocation reaction which will lead to the shorter chain formation of $\alpha$-cellulose compounds.

The compounds produced by both thermal and catalytic hydrocracking reactions were groups of ketone, aldehyde, and carboxylic acids, which are 1-hydroxy-2-propanone $\left(\mathrm{C}_{3} \mathrm{H}_{6} \mathrm{O}_{2}\right)$, 2-furancarboxaldehyde $\left(\mathrm{C}_{5} \mathrm{H}_{4} \mathrm{O}_{2}\right)$, acetic acid $\left(\mathrm{C}_{2} \mathrm{H}_{4} \mathrm{O}_{2}\right)$, formic acid $\left(\mathrm{CH}_{2} \mathrm{O}_{2}\right)$, and propanoic acid $\left(\mathrm{C}_{3} \mathrm{H}_{6} \mathrm{O}_{2}\right)$ as presented in Table4. The products are carbon compounds consisting of a short carbon chain with the presence of oxygen atoms. In the thermal (without the use of a catalyst), a compound containing a long carbon chain was found 
RASĀYAN J. Chem.

Vol. 14 | No. 3 |1965-1971| July - September | 2021

as the last peak in the analytical chromatogram, that is 1,1-diisobutoxybutane $\left(\mathrm{C}_{12} \mathrm{H}_{26} \mathrm{O}_{2}\right)$. This compound was not found as the result of other catalytic hydrocracking. It indicates that the thermal reaction is less optimal to crack the long chain of cellulose into a shorter carbon chain. However, this process carries out a deoxygenation reaction so that it produces hydrocarbon that has great potential as a biofuel.

Table-4: The Liquid Product Selectivity of Hydrocracking of Pyrolyzed $\alpha$-cellulose

\begin{tabular}{c|c|c|c|c|c}
\hline \multirow{2}{*}{ Compound } & \multicolumn{5}{|c}{ Product Percentage (\% Area) } \\
\cline { 2 - 6 } & \multirow{2}{*}{ Pyrolysis } & \multicolumn{5}{|c}{ Hydrocracking } \\
\cline { 3 - 6 } & & Thermal & Co/C800 & Ni/C800 & Zn/C800 \\
\hline 1-hydroxy-2-propanone & 5.49 & 16.63 & 18.09 & 24.11 & 24.32 \\
\hline 2-furancarboxaldehyde & 12.23 & 7.45 & 10.24 & 7.86 & 9.63 \\
\hline Acetic acid & 6.17 & 19.01 & 20.28 & 21.89 & 22.34 \\
\hline Formic acid & 1.59 & 3.67 & 5.35 & 5.50 & 5.04 \\
\hline Propanoic acid & 1.80 & 3.40 & 5.69 & 2.99 & 2.29 \\
\hline 1,1-diisobutoxybutane & - & 6.57 & - & - & - \\
\hline
\end{tabular}

\section{CONCLUSION}

The Co, Ni, and Zn metal catalysts have successfully impregnated on mesoporous carbon from Merbau wood sawdust. The carbon-based sawdust was carbonized at temperature variations of 500,600, 700, and $800{ }^{\circ} \mathrm{C}$ expressed as $\mathrm{C} 500, \mathrm{C} 600, \mathrm{C} 700$, and C800 accordingly. The GSA result shows that $\mathrm{C} 800$ has the largest specific surface area $\left(164.60 \mathrm{~m}^{2} \mathrm{~g}^{-1}\right)$ which is more favorable with an average pore diameter of 3.8 $\mathrm{nm}$. The SEM images exhibit a layered and irregularly porous carbon surface. According to FTIR analysis, among all the carbons, $\mathrm{C} 800$ has been completely decomposed and was chosen as several catalysts support. $\mathrm{Zn} / \mathrm{C} 800$ had the highest metal content with $0.88 \mathrm{wt} . \%$ as well as the highest acidity with $9.68 \mathrm{mmol} \mathrm{g}^{-1}$. Each catalyst has its selectivity percentage for the resulted hydrocracking product compounds. The three main compounds produced were 1-hydroxy-2-propanone $\left(\mathrm{C}_{3} \mathrm{H}_{6} \mathrm{O}_{2}\right)$, acetic acid $\left(\mathrm{C}_{2} \mathrm{H}_{4} \mathrm{O}_{2}\right)$, and 2furancarboxaldehyde $\left(\mathrm{C}_{5} \mathrm{H}_{4} \mathrm{O}_{2}\right)$.

\section{ACKNOWLEDGEMENT}

The authors thank the Indonesian Ministry of Technology Research and Higher Education, the Republic of Indonesia for the financial support under the scheme of PDUPT research grant 2020 (Contract number: 2563/UN1.DITLIT/DIT-LIT/LT/1029).

\section{REFERENCES}

1. A. Deneyer, T. Renders, J. Van Aelst, S. Van den Bosch, D. Gabriëls, and B.F. Sels, Current Opinion in Chemical Biology, 29, 40(2015), https://doi.org/10.1016/j.cbpa.2015.08.010

2. D.M. Alonso, J.Q. Bond, and J.A. Dumesic, Green Chemistry, 12, 1493(2010), https://doi.org/10.1039/C004654J

3. M.J. Climent, A. Corma, and S. Iborra, Green Chemistry, 16, 516(2014), https://doi.org/10.1039/C3GC41492B

4. J.A. Geboers, S. Van de Vyver, R. Ooms, B. Op de Beeck, P.A. Jacobs, and B.F. Sels, Catalysis Science \& Technology, 1, 714(2011), https://doi.org/10.1039/C1CY00093D

5. A. Deneyer, T. Ennaert, G. Cavents, J. Dijkmans, J. Vanneste, C.M. Courtin, M. Dusselier, and B.F. Sels, Green Chemistry, 18, 5594(2016), https://doi.org/10.1039/C6GC01644H

6. S. Van der Vyver, J. Geboers, P.A. Jacobs, and B.F. Sels, ChemCatChem, 3, 82(2011), https://doi.org/10.1002/cctc.201000302

7. H. Kusumastuti, W. Trisunaryanti, I.I. Falah, and M.F. Marsuki, Rasayan Journal of Chemistry, 11, 522(2018), https://doi.org/10.31788/RJC.2018.112206

8. A. Galadima and O. Muraza, Energy Conversion and Management, 105, 338(2015), https://doi.org/10.1016/j.enconman.2015.07.078

9. R.C. Baliban, J.A. Elia, and C.A. Floudas, Industrial \& Engineering Chemistry Research, 52, 3381(2013), https://doi.org/10.1021/ie3024643

10. H. Jahangiri, J. Bennett, P. Mahjoubi, K. Wilson, and S. Gu, Catalysis Science \& Technology, 4, 2210(2014), https://doi.org/10.1039/C4CY00327F 
RASĀYAN J. Chem.

Vol. 14 | No. 3 |1965-1971| July - September | 2021

11. V.K. Venkatakrishnan, W.N. Delgass, F.H. Ribeiro, and R. Agrawal, Green Chemistry, 17, 178(2015), https://doi.org/10.1039/C4GC01746C

12. N.R. Singh, D.S. Mallapragada, R. Agrawal, and W.E. Tyner, Biomass Conversion and Biorefinery, 2, 141(2012), https://doi.org/10.1007/s13399-012-0043-5

13. W. Marquardt, A. Harwardt, M. Hechinger, K. Kraemer, J. Viell, and A. Voll, AIChE Journal, 56, 2228(2010), https://doi.org/10.1002/aic. 12380

14. R.H. Venderbosch, A.R. Ardiyanti, J. Wildschut, A. Oasma, and H.J. Heeres, Journal of Chemical Technology and Biotechnology, 85, 674(2010), https://doi.org/10.1002/jctb.2354

15. F. Mercader, P.J.J. Koehorst, H.J. Heeres, S.R.A. Kersten, J.A. Hogendoorn, AIChE Journal, 57, 3160(2011), https://doi.org/10.1002/aic.12503

16. W. Trisunaryanti, E. Suarsih, Triyono, and I.I. Falah, RSC Advances, 9, 1230(2019), https://doi.org/10.1039/C8RA09034C

17. F. Cherubini, Energy Conversion and Management, 51, 1412(2010), https://doi.org/10.1016/j.enconman.2010.01.015

18. W. Trisunaryanti, Triyono, and D. A. Fatmawati, Rasayan Journal of Chemistry, 13, 723(2020), https://doi.org/10.31788/RJC.2020.1315514

19. Triyono, W. Trisunaryanti, D.D. Ristiana, and L.P. Hastuti, Oriental Journal of Chemistry, 35, 643(2019), https://doi.org/10.13005/ojc/350219

20. I.I. Falah and Triyono, Journal of Chemistry and Chemical Engineering, 4, 22(2010).

21. F.W. Artanti, W. Trisunaryanti, M. Pongsendana, Triyono, I.I. Falah and M.F. Marsuki, Rasayan Journal of Chemistry, 11, 1433(2018), https://doi.org/10.31788/RJC.2018.1143073

22. D. Santi, Triyono, W. Trisunaryanti, and I.I. Falah, Asian Journal of Chemistry, 32, 810(2020), https://doi.org/10.14233/ajchem.2020.22460

23. D. Santi, Triyono, W. Trisunaryanti, and I.I. Falah, Journal of Environmental Chemical Engineering, 8, 103735 (2020), https://doi.org/10.1016/j.jece.2020.103735

24. Q. Li, R. Jiang, Y. Dou, Z. Wu, T. Huang, D. Feng, J. Yang, A. Yu, D. Zhao, Carbon, 49, 1248(2011), https://doi.org/10.1016/j.carbon.2010.11.043

25. C.R. Correa, T. Otto, A. Kruse, Biomass and Bioenergy, 97, 53(2017), https://doi.org/10.1016/j.biombioe.2016.12.017

26. P.S. Thue, E.C. Lima, J.M. Sieliechi, C. Saucier, S.L.P. Dias, J.C. Vaghetti, F.S. Rodembusch, F.A. Pavan, Journal of Colloid and Interface Science, 486, 163(2017), https://doi.org/10.1016/j.jcis.2016.09.070

[RJC-5956/2020] 